REFLEKSI HUKUM

Jurnal Ilmu Hukum
p-ISSN 2541-4984 | e-ISSN 2541-5417

Volume 6 Nomor 1, Oktober 2021, Halaman 71-86

DOI: https:// doi.org/10.24246/jrh.2021.v6.i1.p71-86

Open access at: http:// ejournal.uksw.edu/refleksihukum

Penerbit: Fakultas Hukum Universitas Kristen Satya Wacana

\title{
TRADISI NGEMBLOK DALAM PERKAWINAN DAN IMPLIKASINYA TERHADAP PENGUASAAN HARTA DI KOMUNITAS NELAYAN PANDANGAN WETAN REMBANG
}

\author{
Agus Sudaryanto \\ Fakultas Hukum Universitas Gajah Mada|agus.sudaryanto@mail.ugm.ac.id
}

\begin{abstract}
A R T I C L E I N F O
Article history:

Received

28 Mei 2021

Revised

20 Agustus 2021

Accepted

26 November 2021

Kata-kata Kunci:

Tradisi ngemblok; Masyarakat nelayan;

Penguasaa harta.

Abstrak

Di lingkungan masyarakat nelayan Rembang inisiatif perkawinan datang dari pihak wanita yang dikenal dengan nama ngemblok. Tadisi ngemblok merupakan hukum adat yang masih eksis dan dijalankan oleh masyarakat nelayan. Dalam rangka mempertahankan tradisi ngemblok, sanksi akan diberikan bagi warga yang tidak menjalankan. Penelitian ini fokus untuk mengetahui tradisi ngemblok dalam perkawinan pada komunitas nelayan Desa Pandangan Wetan Rembang. Di samping itu, untuk mengetahui pula tentang pelaksanaan tradisi ngemblok dan implikasinya dalam penguasaan harta perkawinan. Hasil penelitian menunjukkan, alasan komunitas nelayan Desa Pandangan Wetan menjalankan tradisi ngemblok dikarenakan tradisi yang sudah turun menurun, demi harga diri dan jaminan ikatan yang serius menuju perkawinan.
\end{abstract}

Keywords:

Ngemblok tradition;

Fisherman

community; The

control of marital property.

\begin{abstract}
In the fishermen's community of Rembang a marriage proposal is initiated by the fiancée's family, called ngemblok. Ngemblok is an existing customary law which is still embraced by the fishing community. In order to maintain the tradition of ngemblok, sanctions will be given to community members violating the customary law. This study aims to determine the various reasons of the fishermen's community of Pandangan Wetan, Rembang. Apart from that, it aims to find more on the implementation of ngemblok and its implications on marital property control. The result of this research indicates that the reason behind this tradition is prompted by its inheritance value, self-esteem, and assurance to a more secure marriage. The process of Ngemblok begins with an introduction, dating, and assessment of a more serious relationship to marriage.
\end{abstract}




\section{PENDAHULUAN}

Artikel ini merupakan hasil penelitian empiris tentang tradisi ngemblok dalam perkawinan pada komunitas nelayan Desa Pandangan Wetan, Rembang, Jawa Tengah. Dari penelitian yang dilakukan dapat diketahui bahwa masyarakat nelayan di Desa Pandangan Wetan yang didominasi Suku Jawa masih menjalankan tradisi ngemblok secara turun temurun. Dalam tradisi tersebut, pihak perempuan berinisiatif melamar kepada pihak laki-laki dengan disertai sejumlah barang hantaran. ${ }^{1}$ Hal ini sangat mungkin terjadi karena masyarakat nelayan berbeda dari masyarakat lain, seperti masyarakat petani ataupun perkotaan. Masyarakat nelayan memiliki pola-pola kebudayaan yang berbeda dari masyarakat lain sebagai hasil interaksi mereka dengan lingkungan beserta sumber daya yang ada di dalamnya. Pola-pola kebudayaan tersebut menjadi kerangka berpikir atau referensi perilaku masyarakat nelayan dalam menjalani kehidupan sehari-hari.

Tradisi ngemblok berbeda dengan proses perkawinan pada masyarakat Jawa secara umum di mana inisiatif datang dari pihak calon suami yang melakukan lamaran. Berkaitan masalah perkawinan, Sudiyat menyatakan bahwa proses perkawinan dengan didahului pinangan atau lamaran merupakan ciri umum dalam masyarakat Indonesia. Pada umumnya pinangan berasal dari pihak lelaki untuk mengajak pihak wanita untuk menjalin ikatan perkawinan. ${ }^{2}$ Setelah adanya pinangan, di Daerah Jawa Tengah dan Jawa Timur dalam proses perkawinan sering kali diadakan pemberian hadiah perkawinan yang disebut tukon. Maksud dari pemberian tukon bukan untuk membeli calon istri tetapi sebagai bantuan untuk biaya perkawinan dari pihak laki-laki.

Pada komunitas nelayan Desa Pandangan Wetan, tradisi ngemblok masih dipertahankan karena dipandang membawa kebaikan dan akan mendapat reaksi masyarakat jika tidak dijalankan. Reaksi identik dengan sanksi atau konsekuensi yang diberikan masyarakat atas pelanggaran hukum adat. ${ }^{3}$ Hukum adat merupakan nilai-nilai yang hidup dan berkembang di dalam masyarakat suatu daerah. Walaupun sebagian besar hukum adat tidak tertulis, tetapi mempunyai daya ikat yang kuat dalam masyarakat. Ada sanksi atau reaksi tersendiri dari masyarakat jika melanggar aturan hukum adat. ${ }^{4}$ Tradisi ngemblok yang masih dijalankan tersebut menunjukkan bahwa hukum adat yang berkaitan dengan perkawinan masih eksis dan diperlukan dalam kehidupan masyarakat. UndangUndang Nomor 1 Tahun 1974 tentang Perkawinan (UU Perkawinan) tidak mengatur hal-hal yang berkaitan masalah lamaran sehingga memberikan ruang terhadap keberadaan hukum adat diberlakukan oleh suatu masyarakat.

Wawancara dengan Farida, Menantu Juragan Kapal Desa Pandangan Wetan (Desa Pandangan Wetan, 15 Agustus 2018).

Iman Sudiyat, Hukum Adat Sketsa Asas (Liberty 1981) 109.

Jawahir Thontowi, 'Perlindungan dan Pengakuan Masyarakat Adat dan Tantangannya dalam Hukum Indonesia' (2013) 1 (20) Jurnal Hukum Ius Quia Iustum 24.

M. Sholeh, 'Eksistensi Hukum Adat Dalam Polemik Hukum Positif Suatu Kajian Dalam Perspektif Tatanegara' (2013) 1 (3) Ius Kajian Hukum dan Keadilan 538. 
Tradisi ini terkait pula dengan pola pewarisan yang cenderung lebih mengutamakan kepada anak perempuan dari pada anak laki-laki. ${ }^{5}$ Padahal menurut hukum adat Jawa pada dasarnya semua anak, baik laki-laki maupun perempuan mempunyai hak yang sama atas harta warisan orang tuanya. Bagian tiap-tiap anak laki-laki maupun perempuan pada dasarnya sama, bahkan di beberapa desa di Jawa Tengah justru kadang kala anak laki-laki mendapat dua kali bagiannya anak perempuan. ${ }^{6}$ Walaupun pluralitas hukum kewarisan tidak sejalan dengan cita-cita hukum yang sama untuk semua orang tetapi secara faktual masih berjalan sampai saat ini - dan hal itu bersifat negatif. ${ }^{7}$

Apabila suatu perkawinan sudah terwujud, maka guna keperluan hidup diperlukan adanya kekayaan duniawi yang dapat dipergunakan suami istri serta anak-anaknya untuk membiayai ongkos kehidupan sehari-hari. Kekayaan duniawi bagi suami istri inilah disebut dengan harta perkawinan. Dalam suatu masyarakat yang masih mempunyai hubungan kekeluargaan kuat, maka kadangkala kekuasaan kerabat dapat mencampuri urusan harta perkawinan. Namun sebaliknya jika pengaruh dari kerabat lemah, maka keluarga inti atau somah akan memegang peranan dalam penguasaan harta perkawinan. Hal ini dikarenakan keluarga inti hubungannya lebih intens serta karena adanya kecenderungan bagi keluarga inti, makin lama makin lemah dari ikatan kekeluargaan yang lebih luas.

Sesuai penjelasan di atas maka artikel ini bermaksud membahas tiga masalah terkait dengan masih dijalankannya tradisi ngemblok dalam perkawinan pada komunitas nelayan Desa Pandangan Wetan. Pertama, alasan masih dijalankannya tradisi ngemblok oleh komunitas nelayan Desa Pandangan Wetan. Kedua, proses dilakukannya tradisi ngemblok. Ketiga, implikasi tradisi ngemblok terhadap penguasaan harta perkawinan.

Desa Pandangan Wetan dipilih sebagai lokasi penelitian karena komunitas nelayan di sini masih menjalankan tradisi ngemblok dalam proses perkawinan. Subjek penelitian berjumlah 26 orang terdiri dari 6 orang narasumber pemuka agama, kepala desa, dan perangkat desanya sedangkan responden ditentukan melalui teknik purposive sampling. Jumlah keseluruhan 20 keluarga yang mempraktikkan perkawinan ngemblok.

Dalam penelitian lapangan alat utama yang digunakan adalah pedoman wawancara, dengan menggunakan teknik komunikasi langsung. Pedoman wawancara yang digunakan merupakan bentuk semi struktur. Wawancara yang dijalankan menggunakan pertanyaan yang terstruktur, kemudian diperdalam dengan menambah keterangan lebih lanjut tentang tradisi ngemblok di kalangan nelayan dan implikasinya terhadap penguasaan harta perkawinan. Penelitian lapangan ini juga dilengkapi dengan penelitian kepustakaan yang menggunakan studi dokumenter untuk memperoleh bahan-bahan tertulis yang relevan dengan permasalahan penelitian secara umum.

Agus Sudaryanto, 'Pola Pewarisan Di Kalangan Nelayan Desa Pandangan Wetan, Kecamatan Kragan, Kabupaten Rembang' (2009) 21 (1) Jurnal Mimbar Hukum 171, 175.

6 Agus Sudaryanto, 'Aspek Ontologi Pembagian Warisan Dalam Hukum Islam dan Hukum Adat Jawa' (2010) 22 (3) Jurnal Mimbar Hukum 534, 543.

7 M. Burhanuddin Ubaidillah, 'Fenomena Hukum Waris Adat Di Indonesia Antara Keadilan Hukum Dan Keadilan Sosial’ (2020) 3 (2) Jurnal Usratuna 12. 


\section{PEMBAHASAN}

\section{Alasan Komunitas Nelayan Desa Pandangan Wetan Menjalankan Tradisi Ngemblok}

\section{Harga Diri}

Harga diri sering kali diidentikan dengan gengsi merupakan penilaian individu terhadap dirinya baik secara positif maupun negatif, yang diperoleh dari hasil interaksi diri dengan lingkungannya. ${ }^{8}$ Suprayoga menyatakan bahwa harga diri dan malu itu saling berkaitan. Semua orang akan merasa berkewajiban untuk mempertahankan harga diri dan rasa malu, biasanya orang akan sanggup melakukan apa saja demi untuk menjaganya. Orang yang tidak peduli terhadap harga dirinya atau tidak pernah merasa malu, biasanya dianggap tidak beres. Umumnya seseorang akan melakukan sesuatu atau tidak melakukan sesuatu atas dasar pertimbangan rasa malu atau harga diri. ${ }^{9}$

Menurut salah satu tokoh agama Islam yang ditunjuk sebagai imam masjid di lokasi penelitian menyatakan bahwa tradisi nelayan menjalankan ngemblok dalam perkawinan itu susah diubah sebab mereka dalam bertindak tidak mendasarkan pada prinsip-prinsip agama yang dianutnya tetapi hanya dikarenakan gengsi. "Makan gengsi" atau mempertahankan gengsi itu sebetulnya sangat menyusahkan, karena biaya yang dikeluarkan tidak sedikit. Namun demi gengsi keluarga perempuan, maka menjalankan ngemblok dengan cara hutang pun dianggap tidak menjadi masalah.

Masalah gengsi ini dapat dilihat dari besarnya jumlah berbagai barang yang dibawa. Semakin banyak jajanan atau makanan yang dibawa pihak perempuan, maka masyarakat menganggap pihak perempuan itu semakin kaya, terpandang atau tinggi status sosialnya di masyarakat. Faktor gengsi ini dapat dipandang sebagai salah satu penyebab lestarinya sistem ngemblok karena masyarakat di manapun secara naluriah mempunyai rasa gengsi untuk menjaga martabat di lingkungan masyarakatnya.

Bagi nelayan harga diri atau praja merupakan karakter masyarakat Jawa yang sudah berakar sejak lama. Harga diri sangat bermakna bagi kehidupan dalam bermasyarakat dikarenakan praja ini dapat dijadikan sarana untuk menunjukkan suatu kelebihan, kemampuan atau kekuasaan suatu keluarga. Jika suatu keluarga pihak perempuan dapat melakukan prosesi ngemblok dengan barang bawaan yang bernilai tinggi, maka gengsi keluarga tersebut akan diakui oleh masyarakat setempat. Dengan demikian keluarga yang melakukan ngemblok memiliki suatu kebanggaan dan tidak merasa malu dalam pergaulan.

\section{Kelaziman atau Tradisi}

Anake wong sugih kok ora blok-blokan (keturunan orang mampu menjadi aneh jika tidak menjalankan tradisi ngemblok dalam proses perkawinannya) adalah ucapan yang sering terdengar di masyarakat nelayan. Jika tidak

Hayani, 'Harga Diri Dan Kesediaan Dipoligami' (2018) 14 (2) Jurnal Psikosains 172, 177. Imam Suprayogo, 'Harga Diri Dan Rasa Malu' (Gema, 24 Juni 2014) <https://www.uinmalang.ac.id/r/140601/harga-diri-dan-rasa-malu.html> diakses 12 Juli 2021. 
menjalankan tradisi ini oleh masyarakat setempat keluarga tersebut dianggap ora umum (orang yang tidak mengikuti adat kebiasaan dianggap menyimpang) atau tidak mengindahkan hal-hal yang bersifat tradisi. Oleh karena itu, tradisi ngemblok di lingkungan masyarakat nelayan ini masih merupakan hukum adat karena masih ada reaksi masyarakat jika tradisi tersebut tidak dijalankan. Masyarakat setempat akan memberikan reaksi sanksi jika orang yang mampu tidak melakukan tradisi ini. Sanksi yang akan diberikan dari masyarakat adalah berupa gunjingan atau buah bibir dan dianggap tidak memiliki hubungan kemasyarakatan yang baik. Reaksi yang dilakukan oleh masyarakat setempat walaupun bukan berbentuk denda atau sanksi fisik tetapi konsekuensi akan diberikan bagi warga masyarakat yang tidak mengindahkan. Menurut anggapan masyarakat setempat memiliki anak perempuan artinya harus siap banyak kehilangan untuk biaya proses upacara perkawinan. Berdasarkan wawancara dengan Sunardi (27 tahun) sebagai pelaku yang di-emblok ditegaskan bahwa adat ngemblok di wilayah ini adalah pihak perempuan yang harus lebih aktif saat menjelang perkawinan. Baginya karena sudah menjadi tradisi masyarakat setempat, maka ia mengikuti saja kemauan pihak perempuan. ${ }^{10}$

Hadikusuma menegaskan bahwa dilihat perkembangan hidup manusia proses terjadinya hukum itu berasal dari pikiran dan perilaku manusia. Apabila perilaku manusia itu sudah menjadi kebiasaan masyarakat yang harus dilakukan oleh setiap anggota dalam masyarakat yang bersangkutan, maka kebiasaan atau tradisi tersebut sudah menjadi hukum adat.11 Selain itu, Van Vollenhoven berpandangan untuk menentukan hukum adat itu lahir, hidup atau mati tidak dapat dicari dalam sebuah teori tetapi hanya bisa melalui kenyataan. ${ }^{12}$ Oleh karena itu, jika dalam kenyataan suatu norma atau kebiasaan itu ditaati oleh sebagian besar anggota masyarakat, maka berarti suatu tradisi secara teroritik sudah menjadi hukum adat.

\section{Mitos}

Mitos merupakan cerita rakyat yang tidak jarang tidak diketahui penulis atau pembuat mitos tersebut. Pada umumnya dalam mitos terkandung nilai-nilai luhur yang dianggap sakral oleh suatu lingkungan masyarakat. Sebagai pusaka warisan nenek moyang, maka mitos perlu dilestarikan dan diaktualisasikan atau dicari relevansinya dengan kehidupan masa kini. Dalam mitos terkandung filsafat hidup dan juga memiliki kepentingan sosial. Mitos dapat menciptakan legitimasi atau memberikan landasan keabsahan bagi upaya mengatur kehidupan masyarakat. ${ }^{13}$ Mitos sering kali disebut gugon tuhon yang berupa larangan-larang tertentu. Jika larangan tersebut dilanggar, orang jawa percaya akan menerima akibat yang tak baik. Misalkan saja, orang jawa melarang menikah dengan sedulur misan, tumbak tinumbak, geing (kelahiran wage dan pahing), dan mlumah murep. Hal ini akan

Wawancara dengan Sunarto, responden (Desa Pandangan Wetan, 28 Juli 2018)

Hilman Hadikusuma, Pengantar Ilmu Hukum Adat Indonesia (CV Mandar Maju 1992) 1.

Dominikus Rato, Pengantar Hukum Adat (LaksBang Pressindo 2009) 51-52.

Akhmad Arif Junaidi, 'Pergeseran Mitologi Pesantren Di Era Modern:Studi Atas Karomah Kiai

Di Pesantren Futuhiyah Mranggen Demak' (2011) 19 (2) Jurnal Walisongo 511, 522. 
berhubungan keturunan yang mungkin dilahirkan dari sebuah pasangan dan juga berdampak terhadap kelangsungan kehidupan rumah tangganya. ${ }^{14}$

Salah satu responden menyatakan bahwa agar dalam mengarungi kehidupan perkawinan dapat kebahagiaan dan berlangsung sampai akhir hayatnya, maka tradisi ngemblok ini harus dijalankan. Selain itu, ditegaskan lagi bahwa tradisi ngemblok yang masih eksis di kalangan nelayan ini karena sesuai keinginan "danyange". ${ }^{15}$ Dalam pandangan Holleman mitos terhadap fenomena ngemblok ini merupakan konsekuensi adanya salah satu karakter hukum adat Indonesia yang religio-magis. Artinya dalam kehidupan masyarakat itu kadang kala dijumpai sifat atau cara berpikir yang prelogika, animisme, ilmu gaib atau pantangan-pantangan tertentu. Bahkan masih ada pula adanya kepercayaan kepada makhluk halus atau roh. Dengan demikian pandangan masyarakat nelayan yang masih percaya bahwa mitos ngemblok itu merupakan anjuran danyange seharusnya dapat dipahami sebagai suatu kenyataan.

Masyarakat nelayan dalam upaya menjaga tradisi ngemblok, maka diciptakan adanya mitos bahwa leluhurnya terdahulu dalam proses perkawinan melakukan ngemblok. Mitos ini dipertahankan melalui budaya lisan dari satu generasi ke generasi berikutnya. Apabila dicermati dengan ngemblok bagi keluarga perempuan akan mendapatkan tenaga kerja (suami) serta kepastian kelangsungan masalah nafkah keluarga. Dalam hal ini dikarenakan pihak perempuan berwenang memilih calon suami yang ideal harus memenuhi pertimbangan masalah bobot (penghasilan). Dengan pertimbangan masalah bobot, maka adanya jaminan kebutuhan ekonomi keluarga nelayan, maka kelangsungan kehidupan generasi suatu keluarga menjadi berjalan dengan baik.

\section{Sarana Pengikat}

Prosesi perkawinan biasanya setelah perkenalan dilanjutkan dengan lamaran, pertunangan dan akad nikah. Setelah penerimaan lamaran, maka mulailah terjadi hubungan hukum di antara dua pihak, yaitu pihak calon suami dan calon istri sepakat untuk melangsungkan perkawinan. Sebagai simbol atau tanda sifat terang adanya kesepakatan perkawinan tersebut diwujudkan sesuatu yang kongkrit, biasanya disebut panjer (panjar). Dalam ilmu hukum, istilah panjar dikenal dalam hukum adat yakni panjar diartikan sebagai tanda jadi. ${ }^{16}$ Pemberian panjar dalam perkawinan mempunyai fungsi salah satunya menunjukkan kesungguhan keseriusan bukan main-main dalam menjalankan kesepakatan. ${ }^{17}$

Kepastian akan siapa yang akan dijadikan suami itu diwujudkan dalam bentuk tradisi ngemblok tersebut. Lewat tradisi ini pihak perempuan ingin mendapat kepastian mengenai keseriusan laki-laki tersebut untuk mengawini anak gadisnya. Tradisi ngemblok memang hanya berlaku untuk gadis dan jejaka

\footnotetext{
$14 \quad$ Kusul Kholik, 'Mitos-Mitos Penghalang Perkawinan Pada Adat Jawa Dalam Prespektif Hukum Islam (Kajian Terhadap Mitos Perkawinan “Mlumah Murep")' (2018) 1 (2) Jurnal Usratuna 6.

15 Wawancara dengan Muslim, responden (Desa Pandangan Wetan, 22 Oktober 2018).

16 Kartika Law Firm, 'Bolehkah Menolak Kembalikan Uang Panjar Jika Pembelian Batal?' (kartikanews.com, 2019) <http://kartikanews.com/bolehkah-menolak-kembalikan-uang-panjar-jika-pembelian-batal/> di akses 12 Juli 2021.

17 Holijah, 'Asas Kebiasaan Pemberian Uang Panjar Dalam Transaksi Jual Beli Era Pasar Bebas' (2019) 31 (1) Jurnal Mimbar Hukum 31, 37.
} 
saja, seperti yang diungkapkan Bapak $\mathrm{H}$ : “ngemblok itu hanya berlaku untuk jejaka dan gadis, kalau janda akan menikah tidak perlu melakukan ngemblok".

Apabila pihak gadis sudah melakukan ngemblok, maka berarti mereka telah mendapatkan suatu kepastian mengenai calon pendamping. Perkara calon pendamping itu masih akan atau masih bekerja sebagai anak buah kapal di luar negeri selama beberapa tahun hal itu tidak menjadikan masalah. Si gadis akan tetap setia menunggu. Prinsip mereka adalah yang penting ngemblok dahulu, ijab kabulnya bisa dilakukan beberapa tahun kemudian. Dengan demikian jika sudah melalui proses ngemblok, maka sudah dianggap terjadi perjanjian atau kesepakatan untuk melakukan suatu perkawinan di masa yang akan datang.

Perjanjian menurut hukum adat merupakan hubungan hukum antara dua pihak yang terjadi karena adanya kesepakatan dalam bentuk persetujuan karena adanya kepentingan. Oleh karena itu, jika sudah ada kesepakatan, maka menimbulkan adanya perhutangan. ${ }^{18}$ Apabila proses ngemblok sudah dijalani, maka berarti sudah terjadi adanya kesepakatan kedua belah pihak calon suami istri untuk suatu saat akan melangsungkan perkawinan. Di lingkungan nelayan lokasi penelitian tanda kesepakatan atau panjar untuk melakukan perkawinan ini direalisasikan dengan ngemblok. Dalam masyarakat lain tanda jadi untuk melakukan perkawinan ini terdapat bermacam-macam istilah untuk menyebutkannya. Misalnya Aceh: tanda kongnarit; Nias: bobo nibu; Mentawai: sesere; Sulawesi Selatan: passikoq; Lampung: pengikek; Sunda: panyalang dan Jawa: peningset. ${ }^{19}$ Dalam perspektif hukum adat pada umumnya di Indonesia perkawinan itu bukan saja berarti sebagai perikatan perdata, tetapi juga merupakan perikatan adat dan sekaligus merupakan perikatan kekerabatan ketetanggaan. ${ }^{20}$

\section{Menghormati Lelaki}

Prosesi pernikahan yang didahului adanya pelamaran dengan disertai seserahan dari perempuan terhadap pria masih eksis di beberapa wilayah pesisir pantai utara. Alasan filosofisnya adalah egalitarianisme karena pihak perempuan memberikan seserahan kepada pihak pria. Kemudian di lain waktu pihak pria akan membalas dengan pemberikan mahar yang nilainya lebih besar dari seserahan. ${ }^{21}$ Sebagian responden mempunyai pandangan bahwa tradisi ngemblok masih sangat perlu dipertahankan karena tradisi ini sesuai dengan prinsip ajaran Islam dan budaya Jawa, yaitu perempuan itu harus lebih menghormati kaum lelaki. Menurut ungkapan Jawa dikatakan lelaki atau lanang itu walaupun jelek tetapi harus diunggulkan oleh pihak perempuan (lanang: olo ning menang). Budaya Jawa menganut sistem patriarki, suatu sistem yang memposisikan laki-laki lebih tinggi dari wanita dalam keluarga. Seorang istri dalam budaya Jawa dikenal

Hilman Hadikusuma, Hukum Perekonomian Adat Indonesia (PT Citra Aditya Bakti 2001) 65. Ibid, 96.

Santoso, 'Hakekat Perkawinan Menurut Undang-Undang Perkawinan, Hukum Islam Dan Hukum Adat' (2016) 7 (2) Jurnal Yudisia 412, 432.

21 Rizka Nur Laily M, 'Mengungkap Filosofi 'Perempuan Melamar Pria', Tradisi Warga Lamongan yang Masih Eksis' (Merdeka.com, 22 Juni 2020) <https://www.merdeka.com/ jatim/mengungkap-filosofi-perempuan-melamar-pria-tradisi-warga-lamongan-yang-tetap-eksis .html > diakses 12 juli 2021. 
sebagai "konco wingking", artinya istri memiliki peran menemani suami yang bersifat dari belakang, atau sebagai teman mengelola rumah tangga. "Konco wingking" menyiratkan bahwa istri memiliki derajat yang lebih rendah dibandingkan suami karena posisi istri yang berada di belakang suami. Laki-laki memiliki peran sebagai kepala keluarga yang memiliki tugas utama sebagai pencari nafkah, memenuhi kebutuhan sandang, pangan, dan papan. Selain itu, fungsi suami juga menjadi mitra yang diharapkan mampu mengayomi dan membimbing istri. Sebagai istri memiliki peran dalam mengelola keuangan rumah tangga dan mengasuh anak-anaknya. ${ }^{22}$

Salah satu narasumber yang bernama Mualim menegaskan, "menawi priyo dipun suwun dados simah, dipun bandingaken kaliyan ngajak bebrayan kalih wanito, meniko langkung terhormat ingkang dipun suwun". ${ }^{23}$ Menurut mereka dalam ajaran Islampun jika dipahami secara seksama, maka kaum perempuan itu juga dianjurkan untuk menghormati lelaki. Bahkan jika perempuan itu sudah menikah, maka antara suami dan orang tua harus lebih diutamakan suaminya, jika ada dua kepentingan yang bersamaan. Laki-laki sebagai suami biasanya dipandang lebih tinggi dari istri karena mengandung unsur kepala keluarga atau pemimpin yang harus dihormati. Meskipun peran tersebut merupakan tanggung jawab yang mengandung suatu pekerjaan yang harus diselesaikan masing-masing. Meskipun dalam praktiknya semua pekerjaan dalam keluarga bisa saling membantu dan saling melengkapi. Relasi suami istri sulit dipisahkan antara keduanya dalam istilah Jawa disebut dengan garwo (sigaraning jiwo) atau setengah dari nyawa. Keberadaan nyawa tidak mungkin hanya setengah, tapi perlu setengah yang lain untuk bisa menjalankan fungsinya dengan maksimal. ${ }^{24}$

Apabila dicermati penghormatan terhadap lelaki sebagai calon suami yang dapat dianggap berlebih ini, nampaknya dipengaruhi adanya budaya patriarkhi yang tumbuh di masyarakat Jawa. Selain itu, budaya patriarkhi ini dikuatkan dengan tafsir atau pemahaman terhadap sumber Hukum Islam Al Qur'an dan Hadist yang cenderung patriarkhi pula. Hal ini dapat diperhatikan pada bunyi Al Qur'an Surat An Nissa' Ayat 34 yang menegaskan bahwa lelaki itu pemimpin wanita karena lelaki mempunyai kelebihan dibandingkan dengan wanita. Selain itu, Sabda Rasullullah SAW yang menyatakan bahwa :Perkara yang pertama kali ditanyakan kepada perempuan yang sudah menikah di Hari Kiyamat adalah shalat dan kepatuhan pada suami". Penghormatan istri terhadap suami dalam perkawinan dapat dilihat adanya tradisi ngidek endog saat prosesi perkawinan. Tradisi ini dimaknai dalam perkawinan mempelai wanita harus mengabdi kepada mempelai pria seperti mempelai perempuan membasuh kaki mempelai laki-laki. ${ }^{25}$

Farida Agus Setiawati dan Siti Rohmah Nurhayati, 'Kualitas Perkawinan Orang Jawa : Tinjauan Faktor Jenis Kelamin, Usia Perkawinan, Jumlah Anak, Dan Pengeluaran Keluarga' (2020) 13 (1) Jurnal Ilmu Keluarga \& Konsumen 14.

23 Wawancara dengan Mualim, narasumber (Desa Pandangan Wetan, 30 Oktober 2018).

24 Setiawati dan Nurhayati (n 22) 15

25 Mochamad Rifqi Azizi, 'Tradisi Ngidek Endog dalam Pernikahan Adat Jawa dalam Perspektif Urf Studi Kasus Di Kelurahan Karangbesuki Kecamatan Sukun Kota Malang' (2018) 2 (4) Sakina Journal of Family Studies 5. 


\section{Proses Tradisi Ngemblok}

Dalam proses pelaksanaan ngemblok, masyarakat nelayan bersifat terbuka atas pilihan jodoh anak-anaknya. Jika pada masa dahulu ngemblok terjadi atas pilihan orang tua, sekarang jodoh itu berubah kepada pilihan anak gadisnya. Ada beberapa proses yang akan dilalui sebelum terjadinya ngemblok;

Pertama, perkenalan dan pacaran, pada awal pertemuan atau perkenalan ini dapat dilakukan secara perorangan maupun berkelompok. Apabila mereka merasa ada kecocokan, akan dilanjutkan masa pengenalan lebih dalam atau pacaran. Dalam masa ini anak gadis yang berpacaran dengan seorang jejaka, dapat melalui sarana atau cara surat-suratan, bertemu langsung, SMS dan juga saling menelpon. Pacaran melalui sms, seperti dalam kasus yang dialami Wiwin (17 tahun, lulus SMP). "Saya kenal dengan calon suami waktu SMP, saya sering SMS dengannya". ${ }^{26}$ Hal ini mengindikasikan bahwa pacaran era sekarang sangat praktis dan efisien, karena dapat melalui HP, tidak harus datang ke rumah untuk menjalin komunikasi.

Apabila gadis merasa sudah mantap dengan pilihannya, urusan selanjutnya menjadi tanggung jawab orang tuanya. Baik pihak gadis maupun jejaka harus melaporkan hubungannya kepada masing-masing orang tua sehingga jika nanti ada keluarga yang akan bertamu, pihak keluarga laki-laki telah memahami maksud dan tujuannya. Hubungan hukum untuk maksud perkawinan antara bujang dan gadis ini dapat dibuktikan dengan adanya surat-surat, pengakuan para pihak, keterangan saksi baik dari teman, kerabat atau tetangga dan para orang tua. Ibu Daswati mengetahui bahwa anaknya Eva sudah cocok dan cinta dengan Marsudi, apalagi anaknya sudah memintanya agar segera ngemblok. "Eva meminta saya langsung ke Desa Woro, tempat asal Marsudi". ${ }^{27}$

Proses kedua adalah nembung gunem, yaitu keluarga pihak perempuan secara resmi (tembung tuwo) menanyakan kepada pihak keluarga laki-laki, apakah anak jejakanya tidak terikat jodoh atau memiliki hubungan khusus dengan seorang gadis atau tidak. Jika dijawab tidak memiliki hubungan lain, alias masih lajang, maka proses berikutnya dapat dilakukan. Pada saat nembung gunem biasanya pihak perempuan diwakili oleh kedua orang tua gadis. Pada saat bertamu kepada pihak keluarga laki-laki, keluarga pihak perempuan biasanya membawa oleh-oleh, berupa buah-buahan dengan jumlah tidak banyak karena hanya sebagai sarana hubungan keakraban. Barang bawaan saat bertamu ini dapat berupa rokok 1 pres (12 bungkus), biji kopi (kopi mentah), teh dan gula pasir. Ibu Sulastri menuturkan pengalamannya saat kerabat dekatnya akan melakukan nembung gunem. "Waktu itu yang dibawa gula pasir $10 \mathrm{~kg}$, kopi mentah $1 \mathrm{~kg}$, rokok 1 pres, dan buah-buahan sedikit saja". ${ }^{28}$

Ngemblok, antara proses nembung gunem dan ngemblok dapat berjarak beberapa bulan bahkan beberapa tahun tergantung pada kepentingan kedua belah pihak. Ngemblok dilakukan saat hubungan kedua sejoli dianggap sudah matang atau mantap. Kesepakatan diantara keduanya pun sudah dilakukan (tembung mateng). Ukuran kesiapan untuk ngemblok adalah pihak perempuan sudah

26 Wawancara dengan Wiwin, responden (Desa Pandangan wetan, 27 September 2018).

27 Wawancara dengan Daswati, responden (Desa Pandangan Wetan, 27 September 2018).

28 Wawancara dengan Lastri, responden (Desa Pandangan Wetan, 28 September 2018). 
memiliki cukup uang atau biaya untuk melaksanakan proses ngemblok tersebut. Mengingat biaya yang dikeluarkan mencapai jutaan rupiah, maka biasanya keluarga perempuan akan mengumpulkan uang terlebih dahulu. Apabila uang dirasa cukup untuk acara ngemblok barulah proses tersebut dilaksanakan. Sebagian besar responden dalam kasus yang ditemui antara proses ngemblok dengan ijab kabul hanya berjarak 2-3 bulan saja, meski ada pula yang satu orang responden yang meyatakan antara ngemblok dan ijab kabul sampai 3 tahun. Sunarto menegaskan :

"Saya diblok Utami, saat ia masih SMP. Saya tidak menyangka akan diblok secepat itu. Saat ia pulang berlayar dari luar negeri tiba-tiba di rumahnya sudah ada jajanan dari keluarga Utami. Saya menikah 3 tahun kemudian karena masih terikat kontrak dengan kapal Jepang yang berlayar di Canada. ${ }^{29}$

Dalam perspektif lain, tradisi ngemblok yang masih dipraktikkan oleh masyarakat nelayan (tiyang mbelah) khususnya di kawasan Timur wilayah Lasem sampai ke Kecamatan Kragan, mengindikasikan tradisi sisa-sisa jaman matrilineal yang masih ada. Kekuasaan perempuan sangat kuat sehingga dalam masalah perkawinanpun merekalah yang berinisiatif atau melamarnya. Apabila di runut menurut sejarah, maka sisa matrilineal di Jawa khususnya masyarakat nelayan dapat dibuktikan dari beberapa naskah yang ada. Semedi menyebutkan bahwa masyarakat Pantai Utara Jawa di Desa Petungkriyono, Pekalongan, pewarisan tanah menggunakan garis matrilineal. Hal ini dikarenakan untuk melindungi sistem pewarisan tanah yang sudah turun temurun menurut garis perempuan. Dalam rumah tangga pada masyarakat ini terjadi prinsip suami berhak mengolah tanah sedangkan istri yang berhak menjual tanah (wong lanang wenang nggarap, wong wadon wenang adol). ${ }^{30}$ Sementara itu, Zarkazi mendapatkan bukti dalam Kitab Adiparwa, atau saat Prabu Kenya dan Suhita menjadi Ratu di Majapahit pada jaman sebelum Islam datang, Kerajaan Jawa kehidupan masyarakatnya adalah matriarkhat. Namun setelah zaman Islam datang diubah menjadi patriarkhat. ${ }^{31}$

\section{Implikasi Tradisi Ngemblok Terhadap Penguasaan Harta Perkawinan}

Terdapat dua implikasi terhadap tradisi ngemblok yang masih dijalankan di Desa Pandangan Wetan terhadap penguasaan harta perkawinan. Adapun implikasi tersebut menunjukkan adanya pihak suami yang tidak menguasai harta perkawinan dan masalah penerusan penguasaan harta perkawinan. Implikasi yang terjadi merupakan suatu fenomena sosial yang berjalan di praktik kehidupan masyarakat setempat dan masalah ini dapat berbeda dengan lingkungan masyarakat lainnya. Hal ini terjadi dikarenakan implikasi yang ada sesuai dengan situasi dan kondisi serta nilai yang dipandang baik di lingkungan nelayan setempat.

29 Wawancara dengan Sunarto, responden (Pandangan, Wetan, 28 September 2018).

30 Pujo Semedi Hargo Yuwono, 'Wild Pig Hunting in Petungkriono' (2010) 22 (1) Humaniora 11.

31 Effendy Zarkazi, Unsur Islam Dalam Pewayangan (Yayasan Mardi Kintoko 1996) 81-82. 


\section{Suami Tidak Menguasai Harta Perkawinan}

Bagi nelayan, ikan yang menjadi obyek kerja mereka adalah sumber daya yang merupakan milik bersama (common property). Ikan laut adalah benda milik umum yang boleh diambil oleh siapapun, karena sumber daya tersebut berada dalam wilayah suatu komunitas seperti kampung, suku, negara yang diakui sebagai milik eksklusif komunitas tersebut. Kepemilikan sumber daya yang bersifat pribadi tidak ada, sebab kepemilikan selalu bersifat terbuka dan berkait erat dengan luas wilayah maupun mobilitas sumber daya itu sehingga menyulitkan manusia untuk melakukan klaim kepemilikan personal. Berbeda dengan petani yang memiliki kekuasaan sosial dan hak eksklusif terhadap sumber daya yang menjadi obyek mereka. Tanah pertanian dan tanaman budidaya selalu berada di bawah kepemilikan pribadi maupun komunal. Menurut Puspitawati dkk, masyarakat pesisir dan petani yaitu keluarga nelayan tradisional termasuk pada masyarakat miskin dan tertinggal diantara kelompok masyarakat lain. Kondisi ini mengindikasikan bahwa keluarga petani dan nelayan masih rentan dan sangat tergantung terhadap kondisi alam di sekitarnya. ${ }^{32}$

Bagi kaum nelayan hidup bersama di masyarakat dalam pergaulan sehariharinya selalu diwarnai corak kemasyarakatan yang komunal. Oleh karena manusia dalam kehidupan bermasyarakat terikat kepada kebiasaan masyarakatnya. Manusia sebagai individu pada dasarnya dalam kehidupan masyarakat menjadi tidak dapat mempunyai kebebasan yang mutlak. Anggota masyarakat satu dengan lainnya masing-masing memiliki hak dan kewajiban personal maupun sosial. Hal ini dikarenakan interaksi manusia dalam kehidupan bersama memiliki asas fungsi sosial terhadap manusia dan kepemilikan (hak milik).

Prinsip kekayaan milik bersama di kalangan nelayan dalam memahami hak terhadap ikan di lautan ini berimplikasi pada langkanya nelayan lelaki mengurusi harta. Penelitian Sudaryanto pada waris keluarga di Desa Pandangan Wetan menunjukkan bahwa anak laki-laki pada keluarga menengah ke bawah cenderung tidak mendapatkan warisan sebab lelaki dianggap dapat mencari sendiri harta di lautan. Dengan demikian hanya anak perempuanlah, khususnya yang bungsu yang akan mendapat warisan rumah tabon. ${ }^{33}$ Kondisi seperti ini mengakibatkan masalah harta hanyalah menjadi urusan perempuan sebab mereka umumnya tidak bekerja atau tidak mampu mencari kaya (harta) karena hanya tinggal di rumah sehingga kepada mereka harta para kaum lelaki itu diserahkan untuk dikelola.

Lelaki yang sudah memasuki perkawinan dan sudah berstatus sebagai suami di lingkungan komunitas nelayan tidak begitu peduli terhadap penguasaan harta perkawinan. Sebagai suami akan lebih memfokuskan segala sumber daya yang dimiliki untuk mencari penghasilan bukan pada masalah penguasaan harta. Hal ini didorong oleh suatu nilai kehormatan atau keluhuran bagi lelaki atau suami

\footnotetext{
32 Herien Puspitawati, dkk., 'Relasi Gender, Ketahanan Keluarga Dan Kualitas Pernikahan Pada Keluarga Nelayan Dan Buruh Tani “Brondol” Bawang Merah' (2019) 12 (1) Jurnal Ilmu Keluarga \& Konsumen 2.

33 Sudaryanto, 'Pola Pewarisan Di Kalangan Nelayan Desa Pandangan Wetan Kecamatan Kragan Kabupaten Rembang' (n 5) 175, 177.
} 
untuk tidak memikirkan lagi harta yang sudah dicari asal untuk kepentingan keluarga. Bagi suami sebagai seorang lelaki akan merasa malu atau dipandang tidak terhormat jika sampai dalam rumahtangganya timbul suatu masalah atau konflik masalah harta perkawinan.

Hal ini bukan saja berlaku bagi lelaki yang sudah menikah, bahkan para nelayan lelaki yang masih membujangpun cenderung merelakan harta yang dimiliki untuk adik perempuannya karena kaum perempuanlah yang nantinya akan menerima atau menampung suami di rumah (matrilokal). Apabila adik perempuannya memiliki hak kepemilikan atas rumah tabon, dipandang keluarga perempuan tersebut akan naik harga dirinya sebab menantu laki-laki bakal menempati rumah tabon yang telah disiapkan pihak perempuan. Adanya jaminan tempat tinggal ini, mendorong para laki-laki tidak pernah mengurusi masalah harta. Para lelaki, baik yang masih bujang atau yang sudah menikah di komunitas nelayan ini mempunyai pandangan bahwa hidupnya nanti sudah tenang dan terjamin karena akan berada di rumah perempuan sebagai istrinya.

Di samping itu, pada umumnya lelaki di lingkungan masyarakat nelayan Desa Pandangan Wetan memiliki prinsip yang merupakan kearifan lokal bahwa "wong lanang jangkahe ombo, wong wadon kesrimpit pinjung". Artinya laki-laki itu mampu mencari penghasilan tanpa kendala sebab mereka mampu berjalan dengan lebar (mudah). Sementara perempuan banyak hambatannya karena mereka disibukkan dengan urusan rumah, keluarga, anak-anak, dan sebagainya, sehingga perempuan langkahnya pendek atau banyak hambatan. Implikasi dari ungkapan tersebut adalah laki-laki sebagai suami yang lebih fokus kepada mencari nafkah dan harta dipandang lebih mulia. Bagi perempuan sebagai istri karena ada hambatan yang tidak sebebas laki-laki, maka akan lebih terhormat jika fokus untuk mengurusi kebutuhan domestik rumahtangganya.

Akibatnya dalam masalah harta perkawinan di komunitas nelayan ini, kaum lelaki cenderung tidak begitu mempermasalahkan adanya harta perkawinannya. Nilai yang dianggap baik dan berlaku di masyarakat mbelah atau nelayan adalah jika memungkinkan laki-laki itu harus lebih banyak memberi kepada perempuan, bukan meminta. Bagi suami memberi sesuatu termasuk harta kepada istri itu merupakan suatu kewajiban yang membanggakan. Praktik memberi dan/atau mengalah laki-laki kepada pihak perempuan terhadap harta perkawinan juga terlihat jelas dalam masalah kewarisannya. Bagi anak perempuan bungsu cenderung akan mendapatkan kepemilikan rumah tabon. Sementara laki-laki akan mengalah untuk tidak menerima bagian dari pewarisan, karena semua harta yang ada dalam suatu rumah tangga dapat diberikan kepada saudara perempuannya.

\section{Penerusan Penguasaan Harta Perkawinan}

Berdasarkan penuturan seluruh responden dinyatakan bahwa jika dalam perkawinan pasangan suami istri memiliki anak, maka penguasaan harta perkawinan akan jatuh kepada semua anaknya, baik itu terjadi putusnya perkawinan karena kematian maupun perceraian. Masalah ini menunjukkan bahwa pewarisan itu merupakan proses penerusan harta kekayaan dari suatu generasi ke generasi berikutnya. Hukum waris Adat sangat mengutamakan penerusan harta warisan ditujukan kepada anak keturunannya. 
Berdasarkan hukum adat pada asasnya pewarisan itu berjalan menurun, sehingga anak merupakan ahli waris utama dan pertama. Dengan demikian masalah penguasaan harta oleh anak jika orang tua tidak bersatu lagi bukanlah sesuatu yang aneh. Anak dalam perkawinan merupakan pihak yang paling berhak atas harta kekayaan orang tua, jika orang tua sudah tiada. Namun yang agak berbeda dengan masyarakat yang menganut sistem kekerabatan parental lainnya adalah masalah hak eksklusif anak terhadap harta orang tua. Oleh karena pada umumnya jika putusnya suatu perkawinan melalui jalan cerai, suami dan istri masih berhak menguasai harta perkawinan. Namun di masyarakat nelayan ini menurut penuturan salah satu narasumber Ibu Purwasih dinyatakan bahwa jika terjadi perceraian, maka seluruh harta perkawinan akan jatuh kepada anak keturunannya. Suami istri yang sudah cerai dalam hal ini sudah tidak lagi mempunyai hak untuk menguasai harta perkawinannya. ${ }^{34} \mathrm{Hal}$ ini menunjukkan prinsip menurun pewarisan dalam hukum adat masih berjalan. Seluruh harta perkawinan yang ada dalam perkawinan diperuntukkan untuk anak keturunannya.

Dalam hal perkawinan tidak ada anak, dan pasangan suami istri mengangkat anak, maka anak ini juga berhak mendapatkan sebagian harta dari orang tua angkatnya. Namun hak warisnya tidak sekuat anak kandung, karena anak angkat hanya berhak atas harta bersama atau gana gini, sedangkan harta asal atau bawaan kembali pada saudara-saudara peninggal harta. ${ }^{35}$ Sebagaimana umumnya di keluarga Jawa, kedudukan anak angkat tidak memutuskan pertalian antara anak yang diangkat dengan orang tuanya sendiri.

Di kalangan nelayan lokasi penelitian, dalam kasus pasangan suami istri tidak memiliki anak kandung tetapi memiliki anak pungut atau angkat, maka seluruh harta perkawinan akan jatuh ke tangan anak yang diangkat tersebut. Hal ini dikarenakan dalam masyarakat nelayan pada umumnya tidak membedakan status harta (asal atau bersama), jika sudah ada anak. Dengan demikian anak, baik kandung ataupun angkat disamakan hak warisnya.

Dalam hal ditemui putusnya perkawinan dikarenakan perceraian dan pasangan suami istri tidak memiliki anak, maka berdasarkan pengakuan salah satu responden Bapak Tukin dikatakan bahwa penguasaan harta perkawinan akan didasarkan status harta perkawinan yang ada. Harta bawaan (gono gini) pasangan akan dibawa masing-masing pihak. Kemudian jika ada harta perkawinan atau bersama, maka cenderung akan dibagi menjadi dua bagian untuk masing-masing suami istri. 36

Berkaitan masalah putusnya perkawinan, tidak dapat dihindari akan mengakibatkan adanya perubahan dalam penguasaan harta perkawinan. Hal ini dikarenakan harta perkawinan yang ada akan terjadi perubahan penguasaannya. Sebagaimana diketahui ketika suami istri membentuk rumah tangga tidak dapat dapat dihindari perlunya dukungan harta. Oleh karena itu, masyarakat Jawa sering kali sudah melakukan pewarisan ketika anaknya mulai menikah. Pihak orang tua akan mewariskan sebagian harta perkawinannya sebagai bekal penghidupan bagi anaknya. Di masyarakat Jawa yang menganut sistem

$34 \quad$ Wawancara dengan Ibu Purwasih, narasumber (Desa Pandangan Wetan, 30 Oktober 2018).

35 R Soepomo, Bab-bab Tentang Hukum Adat (PT Pradnya Paramita 1993) 98-99.

36 Wawancara dengan Bapak Tukin, responden (Desa Pandangan wetan, 30 Oktober 2018). 
kekerabatan parental, pewarisan dapat dilakukan ketika pewaris masih hidup atau ketika sudah meninggal dunia. Pewarisan yang dijalankan saat pewaris masih hidup dapat dilakukan saat anak menikah, mencar (berumahtangga mandiri), atau kuat gawe (bekerja). Hal ini dimaksudkan sebagai bekal materiil bagi anak untuk kehidupan keluarganya. ${ }^{37}$

Bagi kehidupan rumah tangga harta perkawinan tidak dapat dipungkiri menjadi salah satu sarana keberlangsungan perkawinan. Keberadaan harta ini dimaksudkan sebagai basis material bagi rumah tangga yang bersangkutan, selain menjadi basis material rumah tangga yang akan dibentuk oleh anak-anak yang dilahirkan dari kesatuan rumah tangga. Dengan demikian jika suatu perkawinan tidak ada anak, maka wajarlah jika harta perkawinan yang ada akan dibagi berdasarkan musyawarah mufakat dengan memperhatikan asas desa (tempat), kala (waktu) dan patra (keadaan).

Apabila pasangan tidak memiliki anak kemudian salah satunya meninggal dunia, maka berdasarkan pengakuan responden dan nara sumber, saudara pihak laki-laki maupun perempuan pihak yang meninggal akan mendapat bagian meskipun sedikit. Pada lingkungan masyarakat Jawa terdapat kecerendungan untuk harta bersama akan dibagi dua bagian, satu bagian untuk suami atau istri yang masih hidup dan satu bagian lainnya diperuntukkan bagi ahli waris dari kerabat pihak yang meninggal dunia.

Masalah ini sesuai prinsip yang hidup di kalangan masyarakat Jawa bahwa harta bersama akan jatuh kepada janda atau duda dan anak, sedangkan harta asal kembali pada saudara-saudara peninggal harta. ${ }^{38}$ Di lokasi penelitian menurut narasumber Ibu Wiwik hanya dijumpai satu orang yang sampai meninggalnya suami tidak mempunyai anak. Berdasarkan penuturannya pembagian dan penguasaan harta perkawinan untuk harta asal akan dikembalikan kepada saudara-saudara suaminya tetapi untuk harta bersama saudara suami hanya diberikan sekedarnya berdasarkan kepatutan. ${ }^{39}$

Penguasaan harta perkawinan yang demikian itu dikarenakan terkait prinsip perempuan nelayan lebih layak mendapatkan bagian harta yang lebih banyak dari lelaki. Oleh karena perempuan lebih sulit untuk mendapatkan harta daripada lelaki. Lelaki mudah mencari harta di laut sedangkan perempuan nelayan tidak dapat melaut. Dalam kaitan ini salah satu tokoh masyarakat Desa Pandangan Wetan menegaskan bahwa orang lelaki itu prinsipnya memberi, bukan meminta. Apabila lelaki meminta kepada pihak perempuan, jika tidak dalam keadaan terpaksa adalah sesuatu tabu dan memalukan. ${ }^{40} \mathrm{Hal}$ ini dikarenakan didasarkan pemikiran masyarakat setempat, bahwa lelaki itu lebih mudah mencari harta jika dibandingkan dengan perempuan. Demi untuk memberikan jaminan kehidupan bagi perempuan dan kehormatan lelaki, maka masalah harta bagi lelaki diidealkan mengalah dan memberikan prioritas kepada perempuan. Dalam kehidupan perkawinanpun juga begitu, jika terjadi pembagian dan penguasaan harta

\footnotetext{
37 Djamanat Samosir, Hukum Adat Indonesia Eksistensi dalam Dinamika Perkembangan Hukum di Indonesia (CV Nuansa Aulia 2013) 332.

Soepomo (n 35) 99.

Wawancara dengan Ibu Wiwik, narasumber (Desa Pandangan Wetan, 30 Desember 2018).

Wawancara dengan Lasnasih, narasumber (Desa Pandangan Wetan, 30 Desember 2018).
} 
perkawinan antara suami dan istri akan cenderung banyak istri daripada suaminya.

\section{PENUTUP}

Tradisi ngemblok merupakan ciri khas proses perkawinan yang dilakukan oleh masyarakat nelayan di kawasan Pantura, khususnya wilayah Lasem sampai daerah Kragan. Tradisi ini dipandang sebagai tradisi masyarakat desa. Adapun alasan masyarakat nelayan masih menjalankan tradisi ngemblok dalam proses perkawinan adalah dikarenakan tradisi yang sudah turun menurun, menghormati kaum lelaki, amanat leluhur, demi harga diri dan menjamin ikatan yang serius menuju perkawinan.

Dalam tradisi ngemblok prosesnya diawali dengan perkenalan, pacaran dan penjajagan hubungan yang lebih serius. Akhirnya dilakukan prosesi ngemblok setelah pihak perempuan siap menikah dan mampu mempersiapkan barang hantaran. Tradisi ngemblok ini mengindikasikan adanya sistem kekerabatan matrilineal yang pernah berlaku di lingkungan masyarakat Jawa.

Penguasaan terhadap harta perkawinan, pada umumnya pihak lelaki tidak menguasai karena suami tidak begitu memikirkan masalah harta yang ada dalam rumah tangga. Namun dalam kasus perceraian atau suami meninggal dunia lebih dahulu, maka penguasaan harta perkawinan menjadi variatif karena sangat tergantung situasi dan kondisi masing-masing keluarga atau rumah tangga yang bersangkutan.

Masyarakat nelayan yang masih mempertahankan tradisi ngemblok yang merupakan living law hendaknya diberikan kebebasan untuk mempertahankannya sehingga dapat dijadikan kekhasan masyarakat setempat. Oleh karena tradisi ini merupakan salah satu kearifan lokal dan tidak bertentangan dengan norma sosial lain yang ada. Tradisi komunitas nelayan yang sangat menghargai dan menempatkan kaum perempuan pada posisi yang menguntungkan ini perlu dijadikan bahan pemikiran terhadap peraturan perundangan yang berkaitan dengan perkawinan dan masalah harta. Kaum perempuan dalam masalah harta hendaknya lebih diprioritaskan dari pada kaum lelaki, asalkan situasi dan kondisi memungkinkan.

\section{DAFTAR REFERENSI}

\section{Buku}

Hadikusuma H, Hukum Perekonomian Adat Indonesia (PT Citra Aditya Bakti 2001). , Pengantar Ilmu Hukum Adat Indonesia (CV Mandar Maju 1992).

Rato D, Pengantar Hukum Adat (LaksBang Pressindo 2009).

Samosir D, Hukum Adat Indonesia Eksistensi dalam Dinamika Perkembangan Hukum di Indonesia (CV Nuansa Aulia 2013).

Soepomo R, Bab-bab Tentang Hukum Adat (PT Pradnya Paramita 1993).

Sudiyat I, Hukum Adat Sketsa Asas (Liberty 1981).

Zarkazi E, Unsur Islam Dalam Pewayangan (Yayasan Mardi Kintoko 1996). 


\section{Jurnal}

Azizi MR, 'Tradisi Ngidek Endog dalam Pernikahan Adat Jawa dalam Perspektif Urf Studi Kasus Di Kelurahan Karangbesuki Kecamatan Sukun Kota Malang' (2018) 2 (4) Sakina Journal of Family Studies.

Hayani, 'Harga Diri Dan Kesediaan Dipoligami' (2018) 14 (2) Jurnal Psikosains.

Holijah, 'Asas Kebiasaan Pemberian Uang Panjar Dalam Transaksi Jual Beli Era Pasar Bebas' (2019) 31 (1) Jurnal Mimbar Hukum.

Junaidi AA, 'Pergeseran Mitologi Pesantren Di Era Modern:Studi Atas Karomah Kiai Di Pesantren Futuhiyah Mranggen Demak' (2011) 19 (2) Jurnal Walisongo.

Kholik K, 'Mitos-Mitos Penghalang Perkawinan Pada Adat Jawa Dalam Prespektif Hukum Islam (Kajian Terhadap Mitos Perkawinan "Mlumah Murep")' (2018) 1 (2) Jurnal Usratuna.

Puspitawati H, dkk, 'Relasi Gender, Ketahanan Keluarga Dan Kualitas Pernikahan Pada Keluarga Nelayan Dan Buruh Tani “Brondol” Bawang Merah’ (2019) 12 (1) Jurnal Ilmu Keluarga \& Konsumen.

Santoso, 'Hakekat Perkawinan Menurut Undang-Undang Perkawinan, Hukum Islam Dan Hukum Adat' (2016) 7 (2) Jurnal Yudisia.

Setiawati FA dan Nurhayati SR, 'Kualitas Perkawinan Orang Jawa : Tinjauan Faktor Jenis Kelamin, Usia Perkawinan, Jumlah Anak, Dan Pengeluaran Keluarga' (2020) 13 (1) Jurnal Ilmu Keluarga \& Konsumen.

Sholeh M, 'Eksistensi Hukum Adat Dalam Polemik Hukum Positif Suatu Kajian Dalam Perspektif Tatanegara' (2013) 1 (3) Ius Kajian Hukum dan Keadilan.

Sudaryanto A, 'Aspek Ontologi Pembagian Warisan Dalam Hukum Islam dan Hukum Adat Jawa' (2010) 22 (3) Jurnal Mimbar Hukum.

, 'Pola Pewarisan Di Kalangan Nelayan Desa Pandangan Wetan, Kecamatan Kragan, Kabupaten Rembang' (2009) 21 (1) Jurnal Mimbar Hukum.

Thontowi J, 'Perlindungan dan Pengakuan Masyarakat Adat dan Tantangannya dalam Hukum Indonesia' (2013) 1 (20) Jurnal Hukum Ius Quia Iustum.

Ubaidillah MB, 'Fenomena Hukum Waris Adat Di Indonesia Antara Keadilan Hukum Dan Keadilan Sosial' (2020) 3 (2) Jurnal Usratuna.

Yuwono PSH, 'Wild Pig Hunting in Petungkriono' (2010) 22 (1) Humaniora.

\section{Website}

Imam Suprayogo, 'Harga Diri Dan Rasa Malu' (Gema, 24 Juni 2014) <https://www.uin-malang.ac.id/r/140601/harga-diri-dan-rasa-malu.html.> di akses 12 Juli 2021.

Kartika Law Firm , 'Bolehkah Menolak Kembalikan Uang Panjar Jika Pembelian Batal?' (kartikanews.com, 2019) <http://kartikanews.com/bolehkah-menolak-kembalikanuang-panjar-jika-pembelian-batal/> di akses 12 Juli 2021.

Rizka Nur Laily M, 'Mengungkap Filosofi 'Perempuan Melamar Pria', Tradisi Warga Lamongan yang Masih Eksis' (Merdeka.com, 22 Juni 2020) <https://www.merdeka.com/jatim/mengungkap-filosofi-perempuan-melamar -pria-tradisi-warga-lamongan-yang-tetap-eksis.html> diakses 12 juli 2021.

\section{Peraturan Perundang-Undangan}

Undang-Undang Nomor 1 Tahun 1974 tentang Perkawinan. 